\title{
OUR GEOGRAPHY CORRESPONDENCE
}

\author{
By JEHIEL S. DAVIS \\ High Sehool, Preseott, Arizona
}

When we took up the study of Geography at the high school in Prescott, Arizona, we began at home. Here, where the county as large as New Jersey has only three high schools, quite a number of pupils come in to the school from distances of from a few miles to almost a hundred miles so that the class has a good first hand knowledge of the whole vicinity. Individually and as a class we made excursions from such as an afternoon field trip to Thumb Butte to a motorcycle trip through Salt River Valley to Ronsevelt Dam and Tonto Cliff Dwellings National Monument. Some of us had been to the Grand Canyon National Park, others to the Petrified Forests National Monument or Montezuma Castle National Monument, so we compared notes and used each others post cards and kodak pictures in the balopticon. We drew plans and sketch maps and followed an outline organizing the information contributed by the different members of the classes into a whole. When this was done each member of the classes wrote a letter from his or her note book to a different high school in North America, Hawaii, or England. Perhaps the most interesting answers received were those from Honolulu, New Orleans, Ponce (Porto Rico), Umatilla (Oregon), and Moosejaw (Saskatchewan), though all of them were good. The following is a sample of the letters sent out and the answers received. Many of the letters including the one from Honolulu contained pictures which we used in the balopticon to illustrate the letters.

\section{Prescott, Arizona \\ Prescott High School \\ April 4, 1919}

\section{Geggraphy Class, \\ MoKinley High School, HoNOLULU, H. I.}

DEAR FRIENDS:

We are writing this in the hope that our Home Geography may be of interest and use to you, also hoping that you will send us back a similar letter giving us your Home Geography which we very much desire to obtain from you first hand. 
Our little city is arranged in a rather irregular rectangle with the main roads leading out at each of the four corners. The one railroad enters and leaves at the north side because of the course of the washes it follows together with the arrangement of the mountains near the city. The town is built around a central plaza in which stands the county courc house, in our estimation a very beautiful building.

Prescott stands at latitude $34^{\circ} 33^{\prime}$ north which is about the same as Santa Barbara (California), Atlanta (Georgia), Fez (Moroceo), Bagdad on the Tigris or Singan Fu, China. This is about $13^{\circ}$ north of where you live. Our longitude is $112^{\circ} 27^{\prime}$ west of Greenwich or about the same as Phoenix, Salt Lake City, and Lethbridge, Alberta and a little west of Hermosillo, Sonora, and Easter Island. This is about $44^{\circ}$ east of you. Prescott is at an elevation of 5,346 feet and that is the reason it is often called the "Mile High City." We are about 4,000 feet higher than Phoenix the capital of Arizona which is only one hundred and eight miles south of here. We are about 1,000 feet higher than Salt Lake City and 1,200 feet lower than Mount Mitchell, North Carolina, the highest eastern peak. This altitude is one of the most important factors in our climate. Our high dry climate is the reason that Prescott is considered such a good health resort and that there are so many sanitariums, especially for tubercular people.

Before I tell you more about Prescott I shall explain a little about the country in which it is located so you will get a clear idea of this part of Arizona. Yavapai County (pronounced Yạạạ pie) is in the west central part of the state. The name is Indian and French dialect for hill country, and that tells something of its physical character. It is about the size of the state of New Jersey or about a quarter larger than the area of the Hawaiian Islands.

The surface of Prescott is dominated by a wash which runs north through the central part of town and joins two branches one of which comes north through the east end and the other east through the northwest corner. Valleys open down to the east and north and there are mountains and hills in the other directions. The country around and in town is very rough although the relief is not great for a mountainous region. There are some rather strange rocky sections, places almost completely covered with large granite rocks in such irregular arrangement that it is impossible to walk across them in places. Sometimes these rocks form high hills but more often large piles.

We think Prescott has a delightful climate even though rather cold in winter. The absolute average temperature for the year is $52.7^{\circ}$, the average of the coldest month, January, is $35.1^{\circ}$ and the warmest month, July, is $72.7^{\circ}$. The extreme temperatures are, absolute minimum $-12^{\circ}$ (below zero) and absolute maximum $+104^{\circ}$ while the average yearly minimum and maximum are $+10^{\circ}$ and $+95^{\circ}$. It seems queer that with these cool temperatures we are only a hundred miles from the Salt River Valley 
orange and cotton country. The difference, of course, is explained by the difference in altitude.

There is a great difference between our rainfall and yours, as we have a yearly average of only 17.4 inches. This fall is quite well distributed the months of highest average being August, 3.2 inches, July 2.85 inches and February 1.96 inches and those of least rain being June .24 inches, May .55 inches, and October .78 inches. Snowfall is included in the above, the months having most being February, then January. The average depth of snow fall is 30.2 inches. Much more is received in the mountains nearby and the linemen of the electric power company as well as many miners use snowshoes in the winter so that these are not at all a novelty in this part of Arizona as so many think.

The relative humidity is approximately $54 \%$, the monthly minimum being $54 \%$ A. м. and $35 \%$ P. M., and maximum $86 \%$ А. м. and $85 \%$ P. м. This is higher than the humidity at Phoenix but of course much lower than that where you live. Here in Arizona we have much sunshine, in fact Prescott receives $86 \%$ of all possible. The winds are gentle and varied, with most from the southwest. The arerage air pressure is about 25 inches of mercury.

Our high altitude controls the forests through the rainfall and humidity. There is some irregularity due to direction of exposure but in general areas above 5,500 feet are forested while those below are desert like. Prescott stands in the edge of the forest. Much of the country round is covered with forests in which yellow pine is the most numerous though in no places are they cut for lumber in this county. Yellow pine is a very pretty tree, rather tall and slender, bearing long needles and I believe quite unlike any tree in your islands. Other native trees and plants are the wild black walnut, wild cherry, white oak, horehound, cascara, piñon and many other pines, cottonwood, mistletoe, and cacti. The most common cacti are the prickly pear, but it is not far to the giant saguaro and such other desert plants as the octillo and mesquite. The saguaro cactus often grows over thirty feet tall.

The wild animals are very different from those which you have. The bobcat, red fox, and coyote with the small animals such as rabbits and skunks are most common. Mountain lion and wild deer are quite numerous although they are too eunning to allow themselves to be seen often.

Agriculture is not extensively practiced in this vicinity for several reasons. Most important are the frosts which come as late as June and as early as September. It is so dry that after a good deal of experimenting with dry farming it is still undecided whether it is worth while or not. The land is so rough that much of it is useless except for grazing which is carried on extensixely. Irrigation farming is successful but more common at lower elevations where there is a longer growing season. In a few years we hope to have many more farms. About five miles northeast of Prescott 
is a small dam, Lake Watson Dam (90 feet high) which stores water for the alfalfa farms in a valley farther to the northeast. There are many small sheltered valleys which are planted in orchards, mostly apple, and some of the finest apples in the country are grown in them. Some good land is not used because it is too far from a railroad. There are very few railroads in Arizona.

The population of Prescott is about 6,000. That may seem very small to you as Honolulu is much larger. However it is not so small as compared with other Arizona eities. Among the people living here there are a few of the native Indians left. Most of them were shipped away to Florida or killed. There are also a number of foreigners, mostly Mexicans.

The one railroad that I have mentioned as passing through here is a branch of the Santa Fé. It leaves the main line at Ash Fork, 65 miles north of here and continues by a roundabout way to Phoenix. The way to come here from Honolulu would be to take a steamer to San Francisco or Los Angeles and come by Santa Fé through Barstow and Parker to Phoenix where you would change to come here. There are two main automobile routes between here and Phoenix, one following the general course of the railroad and the other going direct through the Black Canyon and being 45 miles shorter. A road goes north to Ash Fork and connects with the transcontinental highway, the National Old Trails Road. The Borderland T'rail and Apache Trail go through Phoenix.

The most important industries of the region are mining and cattle grazing, but that of Prescott is the Santa Fé shops. The cattle industry and the rodeo have been made famous by Harold Bell Wright's book "When a Man's a Man" and by the advertising of the Frontier Days celebration held for several days including the 4th of July. Copper and gold are the leading minerals taken out in the region.

We have many points of interest in the vicinity. The greatest of all is the Grand Canyon of the Colorado, in the northern part of the state, now a national park and not only famous for its almost inconceivable size but for its wonderful beauty and coloring. Every year it is visited by thousands of tourists from all parts of the world. Many ride down the winding trail on burros to the edge of the Colorado River over 5,000 feet below. The Petrified Forests National Monument northeast of here is also of great interest with its agatized trees. Some distance east of Prescott is the Montezuma Castle National Monument and Well, ruins of a prehistoric people, as is also Tonto National Monument and Casa Grande Ruin National Park to the south and southeast. Near Tonto is the Roosevelt Dam which stores water to irrigate 189,000 acres of land in the Salt River Valley around Phoenix. It stands 285 feet high and 1,070 feet long and holds back water making a lake 25.5 square miles in area. Walnut Canyon National Monument to the north east of Montezuma Castle is also of interest for cliff ruins. There are Indian inscriptions on the rocks in several 
places, one within easy walk of Prescott. Navajo National Monument to the northeast and Tumacacori National Monument to the south are set aside to preserve interesting Indian relies as is also Papago-Saguaro National Monument in the Salt River Valley in part. This last reserve is also as the name indicates to preserve the giant cactus which grows there among wonderful red rocks and hills. Granite Dells is a tiny valley among great granite boulders near Prescott where an attractive little artificial lake has been built for bathing purposes. Four miles west of town is Thumb Butte, a small but picturesque volcanic neck which rises a little over a thousand feet above town.

We think we have very good schools in Arizona although there are not many and they are not large. In Prescott we have two grade schools and one high school, also a Catholic Academy and a Business College. Our high school has about one hundred students but is as well equipped as most any school in the country according to people who are familiar with schools in various states. There are a number of churches in Prescott including the Congregational, Episcopal, Methodist, Christian Science, and Catholic. The most attractive building is the court house built of local granite although the schools are not far behind and we have a nice library building and railway station. The beautiful Pioneers' Home stands on a rocky hill overlooking the city and just out of town is the nice but small county poor farm.

As school closes in the latter part of June we hope you will answer in time so that we may receive it before then.

$$
\begin{aligned}
& \text { Sincerely, } \\
& \text { Prescott High School Sctence Class, } \\
& \text { Margaret Hitl }
\end{aligned}
$$

\section{McKinley Hige School HoNolulu H. I. April 22, 1919.}

\section{MY DEAR MAINLAND FRIENDS:}

Your letter to the Science classes of our high school was very interesting. My classmates appreciated it very much because it contained a great deal of information concerning your city which in the long run will help us in our studies and perhaps in our travels.

Our islands are lying between latitude $18^{\circ} 55^{\prime}$ and $23^{\circ}$ north and longitude $154^{\circ} 40^{\prime}$ and $162^{\circ}$ west. Honolulu on Oahu is the chief city of the group. It has a fine harbor and is a stopping point for nearly every steamship line that has its route in the Pacific Ocean. A steamer comes in or sails out with freight and passengers on an average of three a day, not including our inter-island boats.

Our business section is just a few blocks from the wharves so you can see that the first thing a tourist approaches when he visits us is the business 
section. Among the business houses are two big newspaper firms, namely The Pacific Commercial Advertiser, a morning paper published every day and the Honolulu Star Bulletin, an evening paper published every day except Sunday. Besides these there are several oriental papers. There are about eight banks and many theaters in the city.

The population in the city alone is about 75,000 which consists of different nationalities, chiefly Chinese, Japanese, and Portugese.

The climate is temperate and plant life is green all the year round. The most important industries are agriculture and commerce. Our chief food products are sugar cane, pineapple, rice, taro, and bananas. There are others such as coffee, coconuts, bread fruit, mangoes, and guavas which grow wild on the mountains. Our sugar plantations are scattered all over the island. One of them is situated a few miles from the business center of Honolulu. Others are found at Ewa, Waipahu, Waianae, Kahuku, and Waimanalo. Sisal and cotton are also grown within the eity limits.

The town is well supplied with parks, has good water and sewer systems (water coming from reservoirs and artesian wells), a well equipped fire department, a fine electric car service to every part of the eity and is lighted with electricity and gas.

We have among our public buildings a library, a museum, a post office, and a capitol building. We have many good roads and fine residences. We also have several large hotels and fine automobile rent service.

The mountains of Oahu are very low, the highest peak having an elevation of only a little over 4,000 feet. Our mountains consist of two long ranges both running from north to south, one on each side. A few wild goats may be found on these mountains.

The tourist visiting here can take an automobile to the museum where he can see many relies of our natives or he could visit several other places of interest such as the Aquarium, the Zoo, Waikiki, Moanalua, the Pali, and Tantalus. At the Aquarium are fish having all the colors of the rainbow. After visiting the Aquarium you can either visit the animals of the zoo or take a dip or ride a surf board in the ocean at the beach of Waikiki. Moanalua has many beantiful private gardens which are open to the public. At the Pali, famous in the history of King Kamahamaha, you can get a fine view of the other side of the island. Tantalus is a low mountain about 2,000 feet high from which you have a full view of the eity by itself and the fine blue ocean surrounding it. If you come to Honolulu sometime in the future don't fail to take a trip around the island because along the way there are many things worth seeing.

Our government resembles yours which includes a governor, secretary, auditor, judges, superintendents of public works and education, treasurer, commissioner of public lands, etc. In connection with the above the federal government maintains a judge, a district attorney, a marslıal, and a collector of customs and internal revenues. 
Education is free, compulsory and universal in our city. The Department of Public Instruction has at its head a superintendent and several commissioners. There are many grammar schools here with grades as far as the eighth. There is also a Normal Training School from which the schools are supplied with teachers. The McKinley High School is the only public high school in Honolulu although there are several private schools which give a course practically the same. The faculty consists of about thirty teachers with a student body of over 500. Our school is overflowing and a new high sehool is to be built within a short time (money already appropriated $b y$ the legislature). The present building is to become a grade school.

Thanking you very much for writing to us, I remain,

Sincerely yours,

YUN FAT LEE

\section{SHANTUNG}

The plains of eastern China, with a fertile soil, easily tilled, and the warm, rainy summers of a monsoon climate, are among the most productive regions of the earth. From ancient times their productivity has been put to the service of man and has supported him in vast numbers. Travelers from the scantily peopled medieval Europe were astounded by the swarming life of Cathay. On page after page of his book Marco Polo tells how he traveled through a succession of "rich and noble" cities. Today the Chinese plains remain one of the very densely populated parts of the world.

Rising island-like of the Chinese plains and projecting for out into the Yellow Sea towards Korea is the rocky peninsula of Shantung. The peninsula, indeed, formerly was an island: alluvial deposits of the Yellow River (Hwang-ho) have joined it to the mainland. The rocky peninsula with a bordering belt of alluvial plain on the west constitutes the province of Shantung.

\section{The Cradle of Chinese Crvilization}

The Chinese people originally came from the west. They traveled down the valley of the Yellow River and settled in Shantung, the name of which signifies "Eastern Mountains." Because 